\title{
Protective Effect of a Microtubule Stabilizer Taxol on Caerulein-induced Acute Pancreatitis in Rat
}

Takashi Ueda, Yoshifumi Takeyama, Kunihiko Kaneda, Masanao Adachi, Harumasa Ohyanagi, and Yoichi Saitoh Department of Surgery (1st Division), Kobe University School of Medicine, Kobe 650, Japan

\begin{abstract}
The effect of taxol, which is a microtubule stabilizer, was examined in a model of acute edematous pancreatitis induced in rat by the administration of caerulein. Prophylactic administration of taxol ameliorated inhibition of pancreatic secretion, increased level of serum amylase, pancreatic edema, and histological alterations in this model. Immunofluorescence studies revealed that taxol stabilized the arrangement of microtubules by the action of promoting tubulin polymerization and prevented inhibition of pancreatic digestive enzyme secretion. In isolated rat pancreatic acini, taxol reversed the inhibition of amylase secretion induced by supramaximal concentrations of cholecystokinin octapeptide and did not affect the binding of cholecystokinin octapeptide to its receptor. The results obtained in this study suggest that microtubule disorganization is the initiating event in caerulein-induced pancreatitis and that the inhibition of pancreatic digestive enzyme secretion by interfering with intracellular vesicular transport due to microtubule disorganization causes caerulein-induced pancreatitis. (J. Clin. Invest. 1992. 89:234-243.) Key words: exocrine pancreas • secretion • exocytosis • cholecystokinin octapeptide • cytoskeleton
\end{abstract}

\section{Introduction}

Acute pancreatitis, which is characterized by pancreatic edema and hyperamylasemia, can be induced in rats by supramaximal stimulation with cholecystokinin $(\mathrm{CCK})^{1}$ analogue caerulein $(1,2)$. In this model, flow of pancreatic juice is markedly reduced (3), secretion of pancreatic digestive enzyme is blocked $(1,4,5)$, and large vacuoles are observed in the cytoplasm of acinar cells $(1,3,6)$. These large vacuoles contain both digestive enzymes and lysosomal enzymes $(6,7)$, and it has been suggested that intracellular activation of digestive enzymes resulting from their colocalization with lysosomal enzymes leads to pancreatic autodigestion. But it is not clear whether the inhibition of digestive enzyme secretion is a cause or a result of caerulein-induced pancreatitis, nor is the mechanism of colocalization of digestive and lysosomal enzymes.

Address correspondence to Dr. Yoshifumi Takeyama, Department of Surgery (1st Division), Kobe University School of Medicine, 7-5-2 Kusunoki-cho, Chuo-ku, Kobe 650, Japan.

Received for publication 12 November 1990 and in revised form 19 September 1991.

1. Abbreviations used in this paper: APMSF, ( $p$-amidinophenyl)methanesulfonyl fluoride; $\mathrm{CCK}$, cholecystokinin; $\mathrm{CCK}_{\mathbf{8}}, \mathrm{CCK}$ octapeptide; MAPs, microtubule-associated proteins.

J. Clin. Invest.

(c) The American Society for Clinical Investigation, Inc.

$0021-9738 / 92 / 01 / 0234 / 10 \$ 2.00$

Volume 89, January 1992, 234-243
Recent studies using a synthetic CCK analogue, CCKJMV-180, which is believed to act as an agonist at the higher affinity class and an antagonist at the lower affinity class of CCK receptors $(8,9)$, have demonstrated that caerulein-induced pancreatitis is mediated by low affinity CCK receptors that inhibit the digestive enzyme secretion (10). But the intracellular signal transduction system functioning beneath low affinity CCK receptor and the mechanism of inhibition of digestive enzyme secretion have not been known at all.

On the other hand, recent experiments have shown that microtubules seem to be involved in the intracellular vesicular transport (11). It has been suggested that secretory vesicles leave the Golgi region carrying newly synthesized proteins to the cell surface along microtubule tracks. Selective targeting of post-Golgi vesicles to a region of the cell surface may require the selective laying down or stabilizing of microtubule pathways from the trans-Golgi network to specific regions of the cell surface. It has been reported that treatments of microtubule-disrupting drugs influence the vectorial secretion of proteins in the polarized Madin-Darby canine kidney epithelial cells (12). Vinblastine and colchicine have been shown to inhibit the amylase release from in vitro mouse pancreas by their microtubule-disrupting action (13). So it is conceivable that the inhibition of digestive enzyme secretion in caerulein-induced pancreatitis occurs due to disorder of intracellular vesicular transport, and that microtubules may be involved in this phenomenon.

Taxol, a plant product isolated from Taxus brevifolia, has been shown to have antitumor and antimitotic activities (14). Antineoplastic activity of taxol has been observed in several classically refractory tumors including cisplatin-resistant ovarian carcinoma in phase II trials and malignant melanoma and non-small cell lung carcinoma in phase I studies (15). Unlike the antimicrotubule agents that induce microtubule disassembly, such as colchicine and the vinca alkaloids, taxol $(5-50 \mu \mathrm{M})$ promotes the polymerization of tubulin and stabilizes microtubules by shifting the dynamic equilibrium toward microtubule assembly in vitro $(16,17)$ and in cultured cells $(18,19)$.

In this study, we investigated the effect of a microtubule stabilizer taxol in a model of rat caerulein-induced pancreatitis. Here we report that stabilizing microtubules prevents caerulein-induced pancreatitis, and discuss the role of microtubules in the process of the onset of caerulein-induced acute pancreatitis.

\section{Methods}

Materials and chemicals. Male Wistar rats (200-250 g wt) were employed. Caerulein was obtained from Kyowa Hakko Kogyo Co., Ltd., Tokyo, Japan. CCK octapeptide $\left(\mathrm{CCK}_{8}\right)$ (sulfate form) was purchased from Peptide Institute Inc., Osaka, Japan. Taxol was supplied from the Drug Synthesis and Chemistry Branch, Division of Cancer Treatment, National Cancer Institute, Bethesda, MD. Intramedic polyethylene tubing (PE-10) for pancreatic duct drainage was purchased from Clay 
Adams, Div. of Becton, Dickinson \& Co., Parsippany, NJ. BSA (fraction V) was from Armour Pharmaceutical Co., Tarrytown, NY. An antitrypsin polyclonal antibody was from Cambridge Medical Technology Corp., Cambridge, MA. An anti- $\beta$-tubulin monoclonal antibody and $\left[{ }^{125} \mathrm{I}\right] \mathrm{CCK}_{8}$ (labeled with Bolton and Hunter reagent, $2,000 \mathrm{Ci}$ / $\mathrm{mmol}$ ) were from Amersham Corp., Arlington Heights, IL. Other materials and chemicals were obtained from commercial sources.

In vivo studies. Taxol, dissolved in DMSO at a concentration of 10 $\mathrm{mM}$ and stored at $-20^{\circ} \mathrm{C}$, was injected subcutaneously to a rat at a dosage of $5 \mathrm{mg} / \mathrm{kg}$ of body wt. An equal volume of DMSO was given to a control rat. Then, the rats were anesthetized with a subcutaneous injection of carbamic acid ethyl ester (urethan) at a dosage of $1.5 \mathrm{~g} / \mathrm{kg}$ of body wt. A midline laparotomy was performed and a PE-10 cannula was introduced into the common biliopancreatic duct for a distance of $0.5 \mathrm{~cm}$ by extraduodenal incision with a ligation of common bile duct at the hilus of the liver. The jugular vein was exposed through a small cervical incision and a polyethylene catheter was placed in the vein. After $2 \mathrm{~h}$ of the administration of taxol, the rats were infused with saline alone or with saline containing caerulein $(0.2 \mu \mathrm{g} / \mathrm{kg}$ per h or $5 \mu \mathrm{g} / \mathrm{kg}$ per h) at a rate of $1.0 \mathrm{ml} / \mathrm{h}$ for $4 \mathrm{~h}$. Pancreatic secretions were collected at 1 -h intervals. After infusion with this agent for $4 \mathrm{~h}$, blood was collected for the serum amylase determination, the pancreas was rapidly removed, and the fat was trimmed off. Pancreatic edema was evaluated by measuring the weight of a pancreas fragment immediately after harvesting (wet $w t$ ) and after desiccation for $48 \mathrm{~h}$ at $60^{\circ} \mathrm{C}$ (dry wt). Pancreatic water contents were calculated as (wet wt-dry wt)/wet wt and were expressed as a percent. Pancreatic tissue fragments were fixed with $10 \%$ formalin. After paraffin embedding and sectioning, tissues were stained with hematoxylin and eosin.

Electron microscopy. The rats were perfused transcardially with $2 \%$ paraformaldehyde, $2.5 \%$ glutaraldehyde in $50 \mathrm{mM}$ phosphate buffer containing $8 \%$ sucrose. Pancreas was removed, cut into small pieces, and immersed in the same fixative overnight at $4^{\circ} \mathrm{C}$. The samples were washed three times with $50 \mathrm{mM}$ phosphate buffer containing $8 \%$ sucrose, postfixed in $1 \% \mathrm{OsO}_{4}, 0.1 \mathrm{M}$ sodium cacodylate $(\mathrm{pH} \mathrm{7.4)}$ for $2 \mathrm{~h}$ at $4^{\circ} \mathrm{C}$, washed three times with distilled water, stained en bloc with $0.5 \%$ aqueous uranyl acetate for $2 \mathrm{~h}$ at room temperature, dehydrated in a graded series of ethanol, and embedded in Epon 812. The samples were cut with a diamond knife on an ultramicrotome (LKB Instruments, Inc., Gaithersburg, MD) and examined by an electron microscope.

Indirect immunofluorescence microscopy. The rats were perfused transcardially with $2 \%$ paraformaldehyde in $50 \mathrm{mM}$ phosphate buffer containing $8 \%$ sucrose. Pancreas was removed, cut into small blocks, and immersed in the same fixative containing $10 \mu \mathrm{M}$ ( $p$-amidinophenyl)methane-sulfonyl fluoride (APMSF), $1 \mathrm{mM}$ EGTA, and $1 \mathrm{mM}$ $\mathrm{MgCl}_{2}$ for a further $3 \mathrm{~h}$ at $4^{\circ} \mathrm{C}$. The fixed tissues were cryoprotected through a range of increasing sucrose concentrations $(10,15,20$, and $25 \%$ ), mounted in OCT embedding medium, quick frozen, and sectioned on a cryostat. The $5-\mu \mathrm{m}$ thick frozen sections collected on poly L-lysine-coated slides were incubated with PBS containing 5\% BSA, 10 $\mu \mathrm{M}$ APMSF, $1 \mathrm{mM}$ EGTA, and $1 \mathrm{mM} \mathrm{MgCl}{ }_{2}$ for $1 \mathrm{~h}$ at room temperature and then with either antitrypsin polyclonal antibody or anti- $\beta$ tubulin monoclonal antibody at a final dilution of 1:500 in PBS containing $1 \% \mathrm{BSA}, 10 \mu \mathrm{M}$ APMSF, $1 \mathrm{mM}$ EGTA, and $1 \mathrm{mM} \mathrm{MgCl}$ for $24 \mathrm{~h}$ at $4^{\circ} \mathrm{C}$. Analogous cryosections were treated with either rabbit or mouse nonimmune immunoglobulin $(10 \mu \mathrm{g} / \mathrm{ml})$, and served as controls. After washing three times with PBS containing $10 \mu \mathrm{M}$ APMSF, 1 $\mathrm{mM}$ EGTA, and $1 \mathrm{mM} \mathrm{MgCl}$, the sections were incubated with fluorescein-labeled goat anti-rabbit or anti-mouse immunoglobulin at a final dilution of $1: 30$ for $4 \mathrm{~h}$ at room temperature. After washing three times with PBS containing $10 \mu \mathrm{M}$ APMSF, $1 \mathrm{mM}$ EGTA, and $1 \mathrm{mM}$ $\mathrm{MgCl}_{2}$, the sections were mounted in PBS containing $20 \%$ glycerine under cover glasses and examined by a fluorescence microscope.

Immunocytochemical staining. The samples used for immunofluorescence studies were sectioned on a cryostat and the sections were incubated with an anti- $\beta$-tubulin monoclonal antibody as described above. Nonimmune mouse immunoglobulin was used as a control.
After washing three times with PBS containing $10 \mu \mathrm{M}$ APMSF, $1 \mathrm{mM}$ EGTA, and $1 \mathrm{mM} \mathrm{MgCl}_{2}$, the sections were incubated with horseradish peroxidase-labeled goat anti-mouse immunoglobulin at a final dilution of 1:20 in PBS containing 1\% BSA, $10 \mu \mathrm{M}$ APMSF, $1 \mathrm{mM}$ EGTA, and $1 \mathrm{mM} \mathrm{MgCl}$ for $12 \mathrm{~h}$ at $4^{\circ} \mathrm{C}$. The samples were washed four times with PBS containing $10 \mu \mathrm{M}$ APMSF, $1 \mathrm{mM}$ EGTA, and 1 $\mathrm{mM} \mathrm{MgCl}{ }_{2}$, washed once with TBS, and stained by oxidized diaminobenzidine.

In vitro amylase secretion. Isolated pancreatic acini were prepared from a male Wistar rat by collagenase digestion and forceful pipetting as described previously (20). Freshly prepared acini were resuspended in an appropriate volume of Hepes-buffered Ringer's solution (Ringer's solution containing $10 \mathrm{mM}$ Hepes at pH 7.4, $0.1 \mathrm{mg} / \mathrm{ml}$ of soybean trypsin inhibitor, $5 \mathrm{mg} / \mathrm{ml}$ of BSA, $11.1 \mathrm{mM}$ glucose, minimal Eagle's medium amino acid supplement, and $1.25 \mathrm{mM} \mathrm{CaCl}_{2}$ ) that was gassed with oxygen before use at a density of $2-3 \mathrm{mg} / \mathrm{ml}$ of protein in a $50-\mathrm{ml}$ polycarbonate Erlenmeyer flask and preincubated for $60 \mathrm{~min}$ at $37^{\circ} \mathrm{C}$ in the presence or absence of taxol. After the preincubation, the acini were resuspended in an appropriate volume of the same fresh solution at a density of $\sim 0.5 \mathrm{mg} / \mathrm{ml}$ of protein. $2-\mathrm{ml}$ aliquots of the acinar suspension were distributed into $25-\mathrm{ml}$ polycarbonate Erlenmeyer flasks, gassed with oxygen for $25 \mathrm{~s}$, and then incubated with indicated doses of $\mathrm{CCK}_{8}$ in the presence or absence of taxol for $20 \mathrm{~min}$ at $37^{\circ} \mathrm{C}$. After the incubation, $1-\mathrm{ml}$ aliquots were taken and immediately centrifuged at $10,000 \mathrm{~g}$ for $20 \mathrm{~s}$. The amylase activity of the supernatant thus obtained was measured. The amylase release was expressed as the ratio of the value of amylase activity released into the medium during the incubation to that of total amylase content. The total amylase content was estimated by measuring the enzymatic activity of a $1-\mathrm{ml}$ aliquot of the unstimulated acinar suspension after disruption of the acinar cells by sonication.

Assay for ${ }^{125}$ I-labeled $\mathrm{CCK}_{8}$-binding to pancreatic acini. The binding assay for $\mathrm{CCK}_{8}$ receptors on pancreatic acini was performed using $\left.{ }^{125} \mathrm{I}\right] \mathrm{CCK}_{8}$ as a tracer by the method of Miller et al. (21) with a slight modification. The acini were suspended in an appropriate volume of Hepes-buffered Ringer's solution at a density of $\sim 0.5 \mathrm{mg} / \mathrm{ml}$ of protein. $1-\mathrm{ml}$ aliquots were distributed into test tubes and incubated for 120 min at $37^{\circ} \mathrm{C}$ with $5 \mathrm{pM}\left[{ }^{125} \mathrm{I}\right] \mathrm{CCK}_{8}$ and various doses of unlabeled $\mathrm{CCK}_{8}$ in the presence or absence of $50 \mu \mathrm{M}$ taxol. At the end of the incubation period, the aliquots were centrifuged at $300 \mathrm{~g}$ for $2 \mathrm{~min}$ at $4^{\circ} \mathrm{C}$. The pellets were obtained, and then washed twice with saline at $4^{\circ} \mathrm{C}$. The washed pellets were dissolved with $0.5 \mathrm{ml}$ of $0.5 \mathrm{~N} \mathrm{NaOH}$ and their radioactivities were determined.

Determinations. Protein concentrations were determined with BSA as a standard protein by the method of Lowry et al. (22). The amylase activity was measured by the method of Irie et al. (23). The radioactivity of ${ }^{125}$ I-labeled samples was determined by an auto well gamma counter (model ARC-251; Aloka, Tokyo, Japan).

\section{Results}

Effect of taxol on in vivo rat pancreatic secretion. The effect of taxol on in vivo rat pancreatic secretion (flow of pancreatic juice and amylase secretion) is shown in Fig. 1. Infusion of caerulein at $0.2 \mu \mathrm{g} / \mathrm{kg}$ per $\mathrm{h}$ for $4 \mathrm{~h}$ caused a maximal stimulation of pancreatic secretion, while caerulein at $5 \mu \mathrm{g} / \mathrm{kg}$ per $\mathrm{h}$ for $4 \mathrm{~h}$ inhibited pancreatic secretion. These observations are comparable to those described previously $(1,3-6)$. Taxol itself did not stimulate pancreatic secretion, but with supramaximal caerulein stimulation $(5 \mu \mathrm{g} / \mathrm{kg}$ per h for $4 \mathrm{~h})$, taxol released the inhibition of flow of pancreatic juice partially and that of amylase secretion nearly completely.

Effects of taxol on serum amylase level and pancreatic water content. The effects of taxol on serum amylase level and pancreatic water content are shown in Fig. 2. Infusion of caerulein at 5 $\mu \mathrm{g} / \mathrm{kg}$ per $\mathrm{h}$ for $4 \mathrm{~h}$ caused hyperamylasemia and pancreatic 

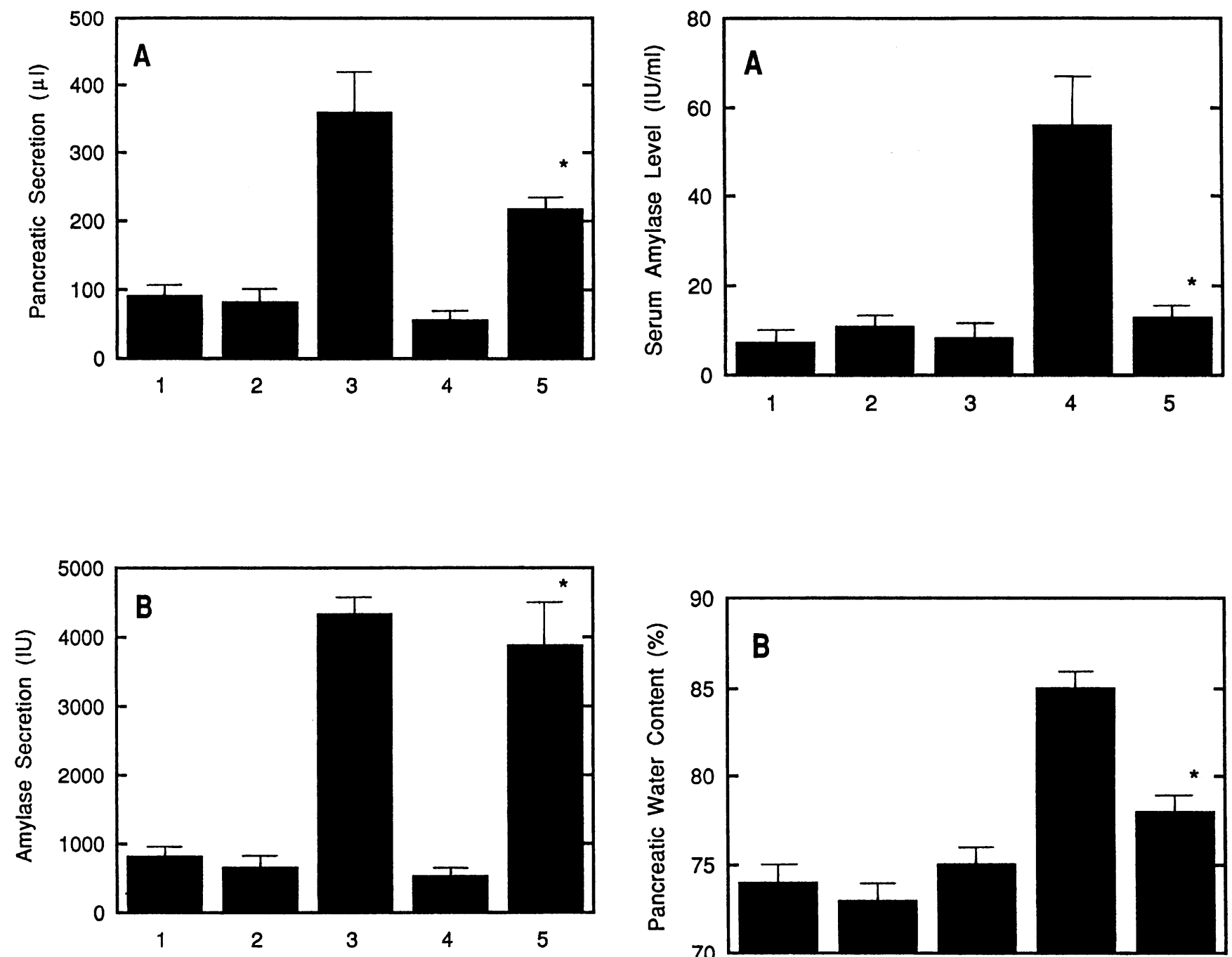

Figure 1. Effect of taxol on in vivo rat pancreatic secretion. Rats were infused with saline alone or saline containing indicated doses of caerulein for $4 \mathrm{~h}$ with or without preceded injection of taxol $(5 \mathrm{mg} / \mathrm{kg}) .(A)$ Flow of pancreatic juice; $(B)$ pancreatic amylase secretion. Lane 1 , saline in the absence of taxol; lane 2, saline in the presence of taxol; lane 3, caerulein $0.2 \mu \mathrm{g} / \mathrm{kg}$ per $\mathrm{h}$ in the absence of taxol; lane 4, caerulein $5 \mu \mathrm{g} / \mathrm{kg}$ per $\mathrm{h}$ in the absence of taxol; lane 5 , caerulein $5 \mu \mathrm{g} / \mathrm{kg}$ per $h$ in the presence of taxol. The results shown are the means $\pm S E$ of at least three independent experiments. *Significantly different from the value of lane 4 by $t$ test $(P<0.01)$.

edema as reported previously $(1,2)$. But, when caerulein at 5 $\mu \mathrm{g} / \mathrm{kg}$ per $\mathrm{h}$ was infused for $4 \mathrm{~h}$ with preceded injection of taxol, serum amylase level stayed almost normal and pancreatic water content was reduced almost to normal range. On macroscopic inspection, pancreatic edema was not observed.

Light microscopic appearance of pancreas. Infusion of caerulein at $5 \mu \mathrm{g} / \mathrm{kg}$ per $\mathrm{h}$ for $4 \mathrm{~h}$ caused interstitial edema and acinar cell vacuolization in the pancreas as reported previously $(1,2)$. In contrast, when caerulein at $5 \mu \mathrm{g} / \mathrm{kg}$ per h was infused for $4 \mathrm{~h}$ with preceded injection of taxol, these histological alterations were not observed (data not shown).

Electron microscopic appearance of pancreatic acinar cell. Intracellular changes were thus observed at the electron microscopic level after 2-h infusion of caerulein at $5 \mu \mathrm{g} / \mathrm{kg}$ per h. Condensing vacuoles were accumulated in the apical region of

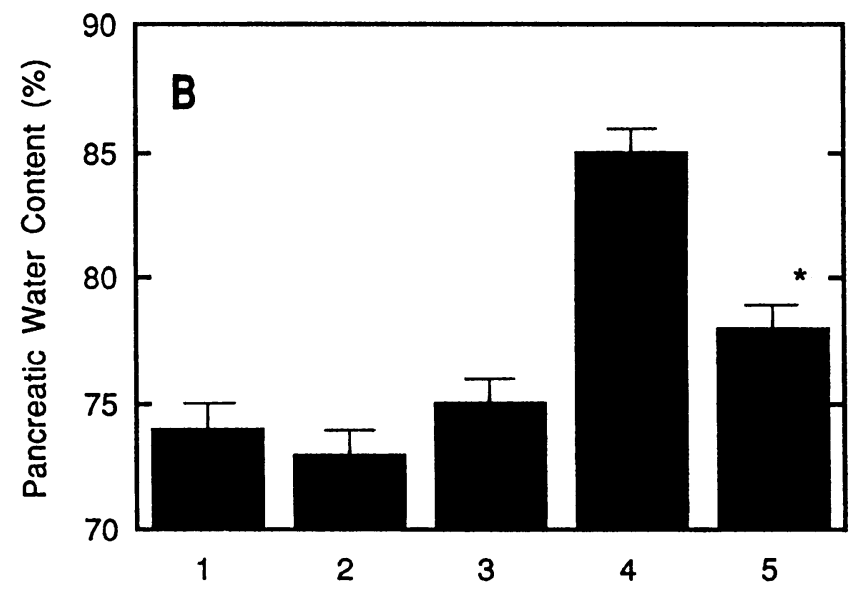

Figure 2. Effects of taxol on serum amylase level and pancreatic water content. Rats were infused as described in the legend to Fig. 1. $(A)$ Serum amylase level; $(B)$ pancreatic water content. The lanes are the same as those in Fig. 1. The results shown are the means \pm SE of at least three independent experiments. *Significantly different from the value of lane 4 by $t$ test $(P<0.05)$.

the cytoplasm and numerous large vacuoles and swollen mitochondria were observed (Fig. $3 \mathrm{~A}$ ) as reported previously $(1,6)$. These large vacuoles in general contained a flocculent material and seemed to be formed as a result of interfering with condensing vacuole maturation as described previously $(1,6)$. After 4-h infusion of caerulein at $5 \mu \mathrm{g} / \mathrm{kg}$ per h, further progression of cell damage was seen. In contrast, when caerulein at 5 $\mu \mathrm{g} / \mathrm{kg}$ per $\mathrm{h}$ was infused for $2 \mathrm{~h}$ and $4 \mathrm{~h}$ with preceded injection of taxol, evidence of pancreatitis as described above was not noted (Fig. $3 \mathrm{~B}$ ). An almost complete absence of the zymogen granules suggests that active secretion of enzymes is occurring.

Effect of taxol on the distribution of trypsin. The frozen sections of rat pancreas were analyzed by indirect immunofluorescence with an antitrypsin polyclonal antibody. In 4-h salineinfused sections (basal state), fluorescence was seen in the apical regions (zymogen granules) of acinar cells and in the acinar lumen (basal secretion) (Fig. $4 A$ ). When caerulein at $0.2 \mu \mathrm{g} / \mathrm{kg}$ 

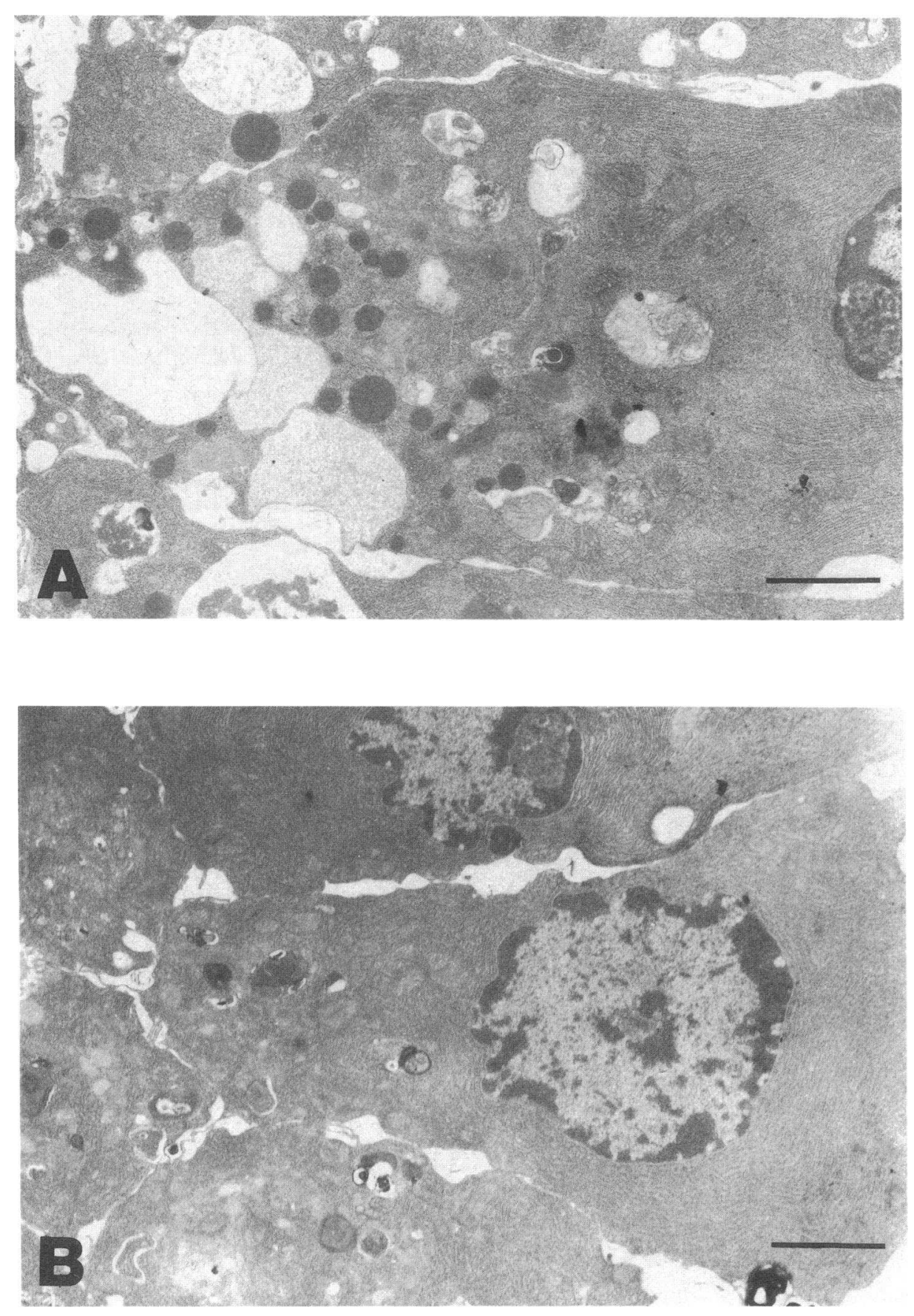

Figure 3. Effect of taxol on electron microscopic appearance of pancreatic acinar cell. Rats were infused with caerulein $5 \mu \mathrm{g} / \mathrm{kg}$ per h for $2 \mathrm{~h}$ with or without preceded injection of taxol $(5$ $\mathrm{mg} / \mathrm{kg}$ ). (A) Caerulein $5 \mu \mathrm{g} / \mathrm{kg}$ per h for $2 \mathrm{~h}$ in the absence of taxol; $(B)$ caerulein $5 \mu \mathrm{g} / \mathrm{kg}$ per $\mathrm{h}$ for $2 \mathrm{~h}$ in the presence of taxol. Bars: $2 \mu \mathrm{m}$. per $\mathrm{h}$ was infused for $4 \mathrm{~h}$, fine fluorescence was seen only in the acinar lumen and pancreatic digestive enzymes secretion seemed to be completed (Fig. $4 \mathrm{~B}$ ). In contrast, when caerulein at $5 \mu \mathrm{g} / \mathrm{kg}$ per h was infused for $4 \mathrm{~h}$ (caerulein-induced pancreatitis), spherical granular fluorescence was seen in the apical regions of acinar cells (Fig. $4 C$ ). This image indicates that the inhibition of pancreatic digestive enzyme secretion occurs in caerulein-induced pancreatitis as so far described $(1,4,5)$. This image of trypsin was also observed after 2-h infusion of caerulein at $5 \mu \mathrm{g} / \mathrm{kg}$ per $\mathrm{h}$ (data not shown). When caerulein at 5 $\mu \mathrm{g} / \mathrm{kg}$ per $\mathrm{h}$ was infused for $4 \mathrm{~h}$ with preceded injection of taxol, in contrast with the image of Fig. $4 C$, the inhibition of pancreatic digestive enzyme secretion was prevented (Fig. 4 D). No significant staining was seen in the control sections.
Effect of taxol on the distribution of $\beta$-tubulin. In the same samples, immunofluorescence studies with an anti- $\beta$-tubulin monoclonal antibody were performed. When saline was infused for $4 \mathrm{~h}$, the microtubule network was seen and seemed to be laid from the supranuclear regions to the acinar lumen in a radial shape (Fig. $5 \mathrm{~A}$ ). In contrast, when saline was infused for $4 \mathrm{~h}$ with preceded injection of taxol, the network fluorescence became stronger and bundles of microtubules were clearly seen (Fig. $5 \mathrm{~B}$ ). In caerulein-induced pancreatitis, the microtubule network changed to a faint fluorescence and seemed to be disassembled and disrupted relatively (Fig. $5 C$ ). This faint fluorescence was also observed after 2-h infusion of caerulein at 5 $\mu \mathrm{g} / \mathrm{kg}$ per h (data not shown). When caerulein at $5 \mu \mathrm{g} / \mathrm{kg}$ per h was infused for $4 \mathrm{~h}$ with preceded injection of taxol, in contrast 

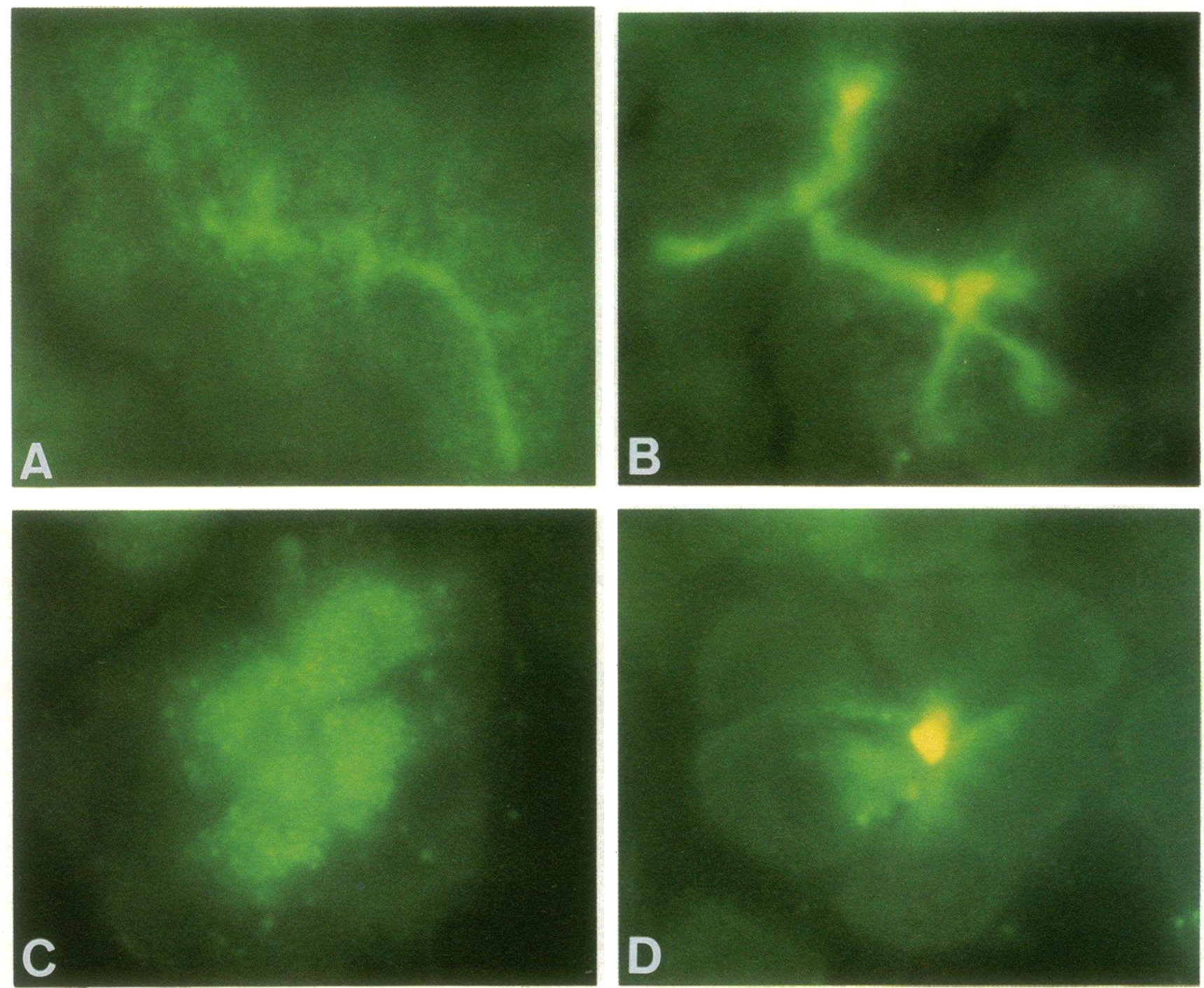

Figure 4. Effect of taxol on the distribution of trypsin. Rats were infused as described in the legend to Fig. 1. After infusion, indirect immunofluorescence staining of exocrine pancreas with an antitrypsin antibody was performed. $(A)$ Saline for $4 \mathrm{~h}$ in the absence of taxol; $(B)$ caerulein $0.2 \mu \mathrm{g} / \mathrm{kg}$ per $\mathrm{h}$ for $4 \mathrm{~h}$ in the absence of taxol; $(C)$ caerulein $5 \mu \mathrm{g} / \mathrm{kg}$ per h for $4 \mathrm{~h}$ in the absence of taxol; $(D)$ caerulein $5 \mu \mathrm{g} / \mathrm{kg}$ per h for $4 \mathrm{~h}$ in the presence of taxol. Magnification, 1250.

with the image of Fig. $5 C$, the microtubule network fluorescence became stronger, and radial microtubules seemed to be stabilized by polymerizing tubulin (Fig. $5 \mathrm{D}$ ). No significant staining was seen in the control sections.

Effect of taxol on microtubules. Immunocytochemical staining using an anti- $\beta$-tubulin antibody linked to horseradish peroxidase was performed to verify the effect of taxol on microtubules. In 4-h saline-infused sections, immunoreactivity with $\beta$-tubulin was observed around zymogen granules in the apical regions (Fig. $6 A$ ). In contrast, when saline was infused for $4 \mathrm{~h}$ with preceded injection of taxol, the immunoreactivity became stronger (Fig. $6 \mathrm{~B}$ ). In caerulein-induced pancreatitis, the immunoreactivity with $\beta$-tubulin was weaker than that in salineinfused sections (Fig. $6 C$ ). This relatively failed immunoreactivity was also observed when caerulein at $5 \mu \mathrm{g} / \mathrm{kg}$ per h was infused for $2 \mathrm{~h}$ (data not shown). When caerulein at $5 \mu \mathrm{g} / \mathrm{kg}$ per $h$ was infused for $4 \mathrm{~h}$ with preceded injection of taxol, the immunoreactivity with $\beta$-tubulin became stronger and radial stabilized microtubules were observed (Fig. $6 \mathrm{D}$ ). No significant staining was seen in the control sections.
Effect of taxol on in vitro amylase secretion. The effect of taxol on in vitro $\mathrm{CCK}_{\mathbf{8}}$-induced amylase secretion from rat pancreatic acini was examined. As has been previously reported (24), amylase secretion was stimulated in a dose-dependent manner at lower concentrations of $\mathrm{CCK}_{8}$ and the maximal rate of amylase secretion was observed at $1 \times 10^{-10} \mathrm{M}$ $\mathrm{CCK}_{8}$, while amylase secretion was inhibited at higher concentrations than $1 \times 10^{-10} \mathrm{M} \mathrm{CCK}_{8}$. Half-maximal inhibition at 1 $\times 10^{-9} \mathrm{M} \mathrm{CCK}_{8}$ and the maximal inhibition at $1 \times 10^{-8}-1$ $\times 10^{-6} \mathrm{M} \mathrm{CCK}_{8}$ were observed. In the presence of $50 \mu \mathrm{M}$ taxol, this inhibition of amylase secretion at higher concentrations (1 $\times 10^{-9}-1 \times 10^{-6} \mathrm{M}$ ) of $\mathrm{CCK}_{8}$ was reversed (Fig. 7). Taxol did not stimulate amylase secretion in the absence of $\mathrm{CCK}_{8}$ nor the presence of $1 \times 10^{-10} \mathrm{M} \mathrm{CCK}_{8}$. While in the presence of 1 $\times 10^{-8} \mathrm{M} \mathrm{CCK}_{8}$, taxol stimulated amylase secretion to the maximal level in a dose-dependent manner. In the presence of $50 \mu \mathrm{M}$ taxol, the inhibition of amylase secretion at $1 \times 10^{-8} \mathrm{M}$ $\mathrm{CCK}_{8}$ disappeared perfectly (Fig. 8). The same results were obtained in the presence of taxol at higher concentrations than $50 \mu \mathrm{M}$ (data not shown). 

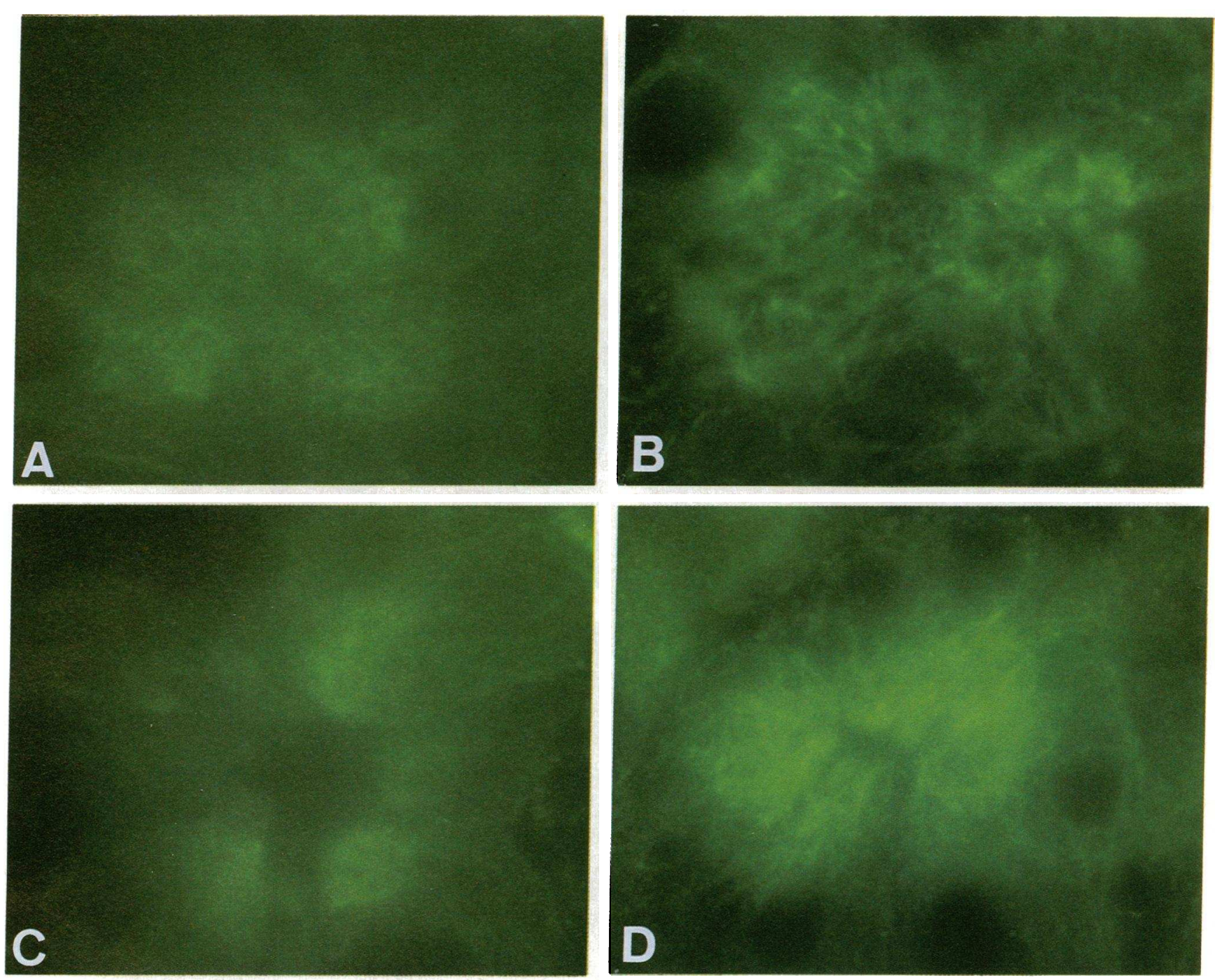

Figure 5. Effect of taxol on the distribution of $\beta$-tubulin. Rats were infused as described in the legend to Fig. 1. After infusion, indirect immunofluorescence staining of pancreas with an anti- $\beta$-tubulin antibody was performed. $(A)$ Saline for $4 \mathrm{~h}$ in the absence of taxol; $(B)$ saline for 4 $\mathrm{h}$ in the presence of taxol; $(C)$ caerulein $5 \mu \mathrm{g} / \mathrm{kg}$ per h for $4 \mathrm{~h}$ in the absence of taxol; $(D)$ caerulein $5 \mu \mathrm{g} / \mathrm{kg}$ per $\mathrm{h}$ for $4 \mathrm{~h}$ in the presence of taxol. Magnification, 1250.

Effect of taxol on ${ }^{125}$ I-labeled $C C K_{8}$-binding to acini. In the last set of experiments, the effect of taxol on the binding of $\mathrm{CCK}_{8}$ to its specific receptor on pancreatic acini was examined. The competitive inhibition of [ $\left.{ }^{125} \mathrm{I}\right] \mathrm{CCK}_{8}$-binding to rat pancreatic acini by unlabeled $\mathrm{CCK}_{\mathbf{8}}$ was studied. This inhibition curve showed two phases, suggesting that $\mathrm{CCK}_{8}$ interacted with two different affinity sites on rat pancreatic acini as reported previously (25). Taxol $(50 \mu \mathrm{M})$ did not affect this inhibition curve of $\left[{ }^{125} \mathrm{I}\right] \mathrm{CCK}_{8}$-binding to rat pancreatic acini (Fig. 9). The same results were obtained in the presence of $5 \mu \mathrm{M}$ and $500 \mu \mathrm{M}$ taxol (data not shown).

\section{Discussion}

In this study, we have first described that stabilizing microtubules by taxol administration removes the inhibition of pancreatic digestive enzyme secretion induced by supramaximal caerulein stimulation and prevents the development of caeruleininduced pancreatitis. These results indicate that inhibition of pancreatic digestive enzyme secretion, resulting from disorder of intracellular vesicular transport due to microtubule disorganization, causes caerulein-induced pancreatitis.

The pharmacology of taxol in humans has been studied during phase I trials for its clinical application as an antineoplastic agent $(15,26)$. From the results of preclinical animal studies and phase I trials of taxol, the recommended phase II trial dose is $200-250 \mathrm{mg} / \mathrm{m}^{2}$. The dose of taxol used in our in vivo studies $(5 \mathrm{mg} / \mathrm{kg})$ is comparable to this dose and sufficient to stabilize microtubules. In fact, it is evident that microtubules were stabilized by taxol in immunofluorescence and immunocytochemical studies with an anti- $\beta$-tubulin antibody. So it is conceivable that taxol exerts in vivo effects in this study. Moreover, the concentration of taxol used in our in vitro studies is approximately comparable to the concentrations at which microtubules were stabilized in vitro $(16,17)$ and in cultured cells $(18,19)$ as reported previously, and the plasma concentration of taxol with a dose of $275 \mathrm{mg} / \mathrm{m}^{2}$ in vivo (26). So the concentrations of taxol chosen for the in vitro studies are reasonable and represent the concentration seen in the organ after taxol injection in vivo. 

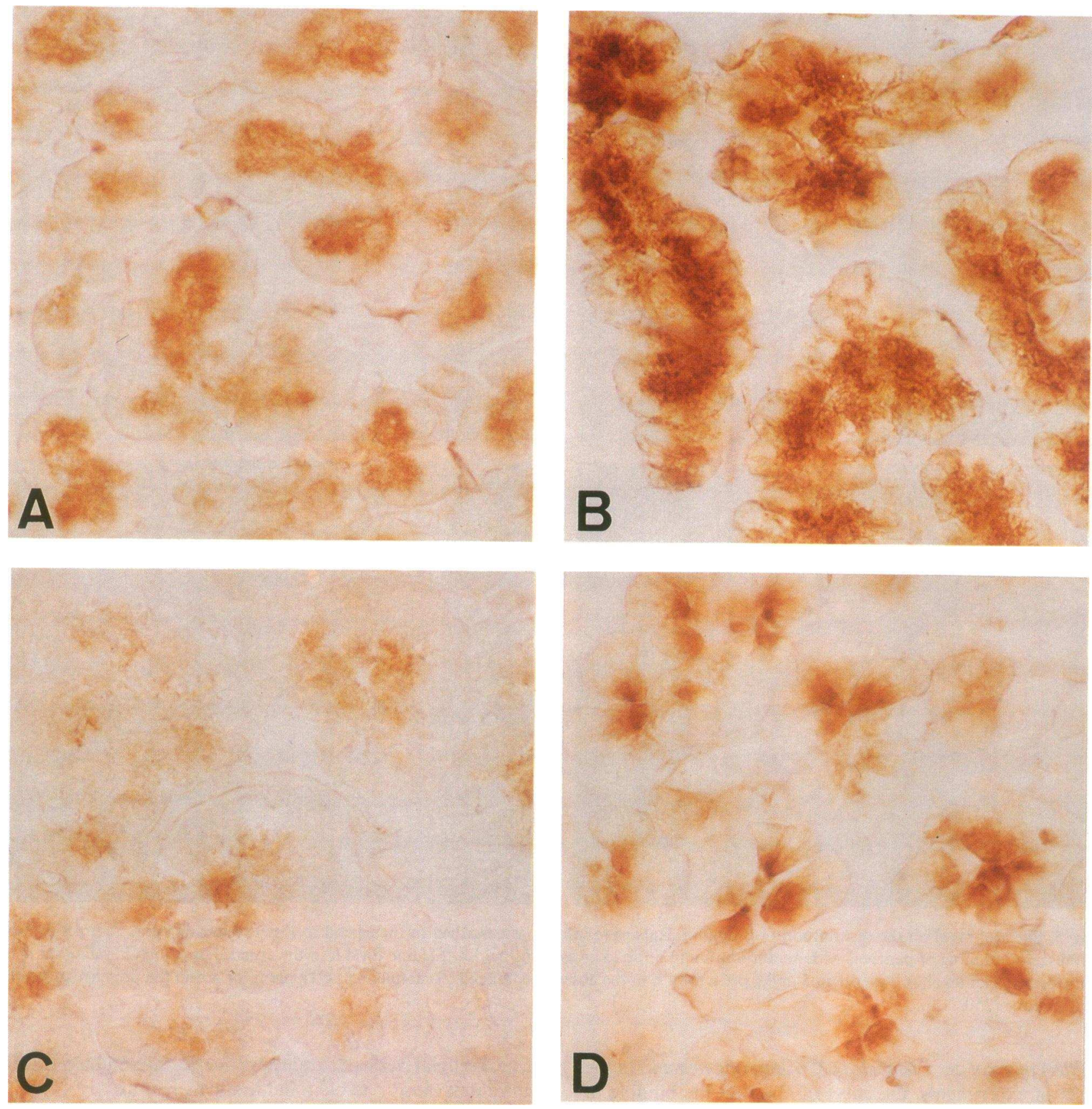

Figure 6. Effect of taxol on microtubules. Rats were infused as described in the legend to Fig. 1. After infusion, immunocytochemical staining of pancreas using an anti- $\beta$-tubulin antibody linked to horseradish peroxidase was performed. $(A)$ Saline for $4 \mathrm{~h}$ in the absence of taxol; $(B)$ saline for $4 \mathrm{~h}$ in the presence of taxol; $(C)$ caerulein $5 \mu \mathrm{g} / \mathrm{kg}$ per $\mathrm{h}$ for $4 \mathrm{~h}$ in the absence of taxol; $(D)$ caerulein $5 \mu \mathrm{g} / \mathrm{kg}$ per h for $4 \mathrm{~h}$ in the presence of taxol. Magnification, 100.

In the results obtained from in vivo studies, taxol removed the inhibition of amylase secretion nearly completely, but that of flow of pancreatic juice incompletely, and normalized serum amylase level nearly completely, but pancreatic water content incompletely. Recent investigation has demonstrated that CCK downregulates vasoactive intestinal peptide and secretin receptors in rat pancreatic acini (27). Since it is generally believed that secretin acts to stimulate a flow of bicarbonateand electrolyte-rich ductular secretion, probably this discrepancy occurs as a result of the downregulation of secretin receptors by caerulein and this part of secretion is considered to be related to endogenous secretin.
Concerning the role of the microtubules in exocytosis, two possible mechanisms have been proposed. One is that microtubules serve as the tracks along which exocytotic vesicles are guided to specific cell surface domains. The other is that microtubules are involved in the maintenance of the structural organization of the Golgi complex. The disruption of the microtubule network would lead to the disorganization of the Golgi complex and would consequently result in inhibition of protein transport. In a model of caerulein-induced pancreatitis, transport from the endoplasmic reticulum to the Golgi cisternae is not altered, but the maturation of condensing vacuoles into zymogen granules is found to be impaired (4-6). There- 


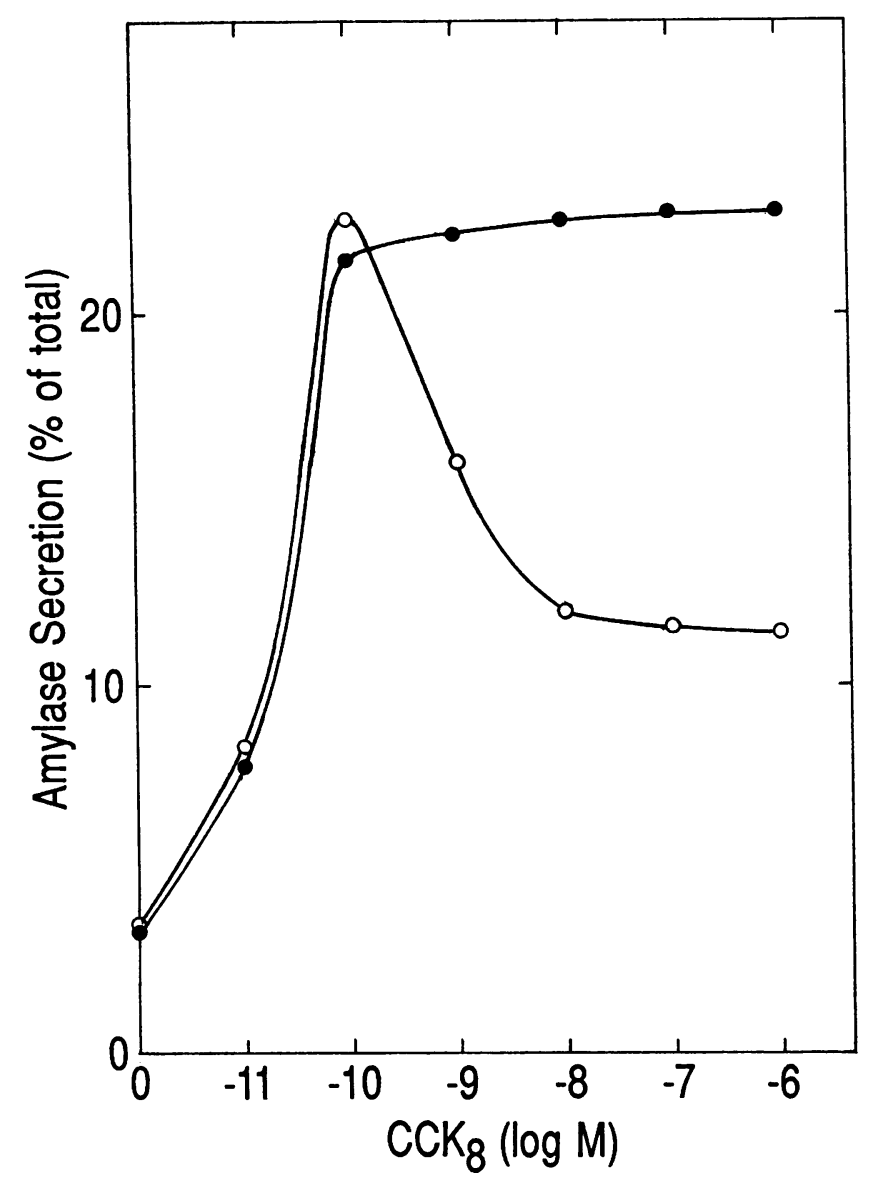

Figure 7. Effect of taxol on in vitro $\mathrm{CCK}_{\mathbf{8}}$-induced amylase secretion. Rat pancreatic acini were incubated with indicated concentrations of $\mathrm{CCK}_{8}$ in the presence or absence of $50 \mu \mathrm{M}$ taxol. (๑), in the presence of taxol; (O), in the absence of taxol. The results shown are representative of three independent experiments.

fore, it is conceivable that disorganization of microtubule tracks in this specific part results in inhibition of digestive enzyme secretion and colocalization of digestive and lysosomal enzymes, and causes caerulein-induced pancreatitis.

It has been shown that caerulein-induced pancreatitis is mediated by low affinity CCK receptors that inhibit digestive enzyme secretion (10), but the transduction mechanism of the low affinity receptor has not been understood at all. In a previous paper (24), we reported that the supramaximal dose of $\mathrm{CCK}_{8}$ inhibits the secretory process post to the protein kinase $\mathrm{C}-\mathrm{Ca}^{2+}$ system and thereby reduces amylase release and proposed that the common secretory process post to the intracellular messenger systems may be inhibited by the supramaximal dose of $\mathrm{CCK}_{8}$. Therefore, from the results in this study, it is conceivable that tubulin, which is a component of microtubules, is a final targeting protein in the signal transduction system of the low affinity receptor, and that disorganized part of microtubules is the common secretory process post to the intracellular messenger systems.

It has been shown that polymerization of tubulin requires GTP, $\mathrm{Mg}^{2+}$, and MAPs. In vitro, taxol promotes the polymerization of tubulin into cold- and calcium-stable microtubules, both in the presence and absence of microtubule-associated proteins (MAPs) as well as of $\operatorname{GTP}(16,17,28)$. Accumulating results have demonstrated that various protein kinases such as

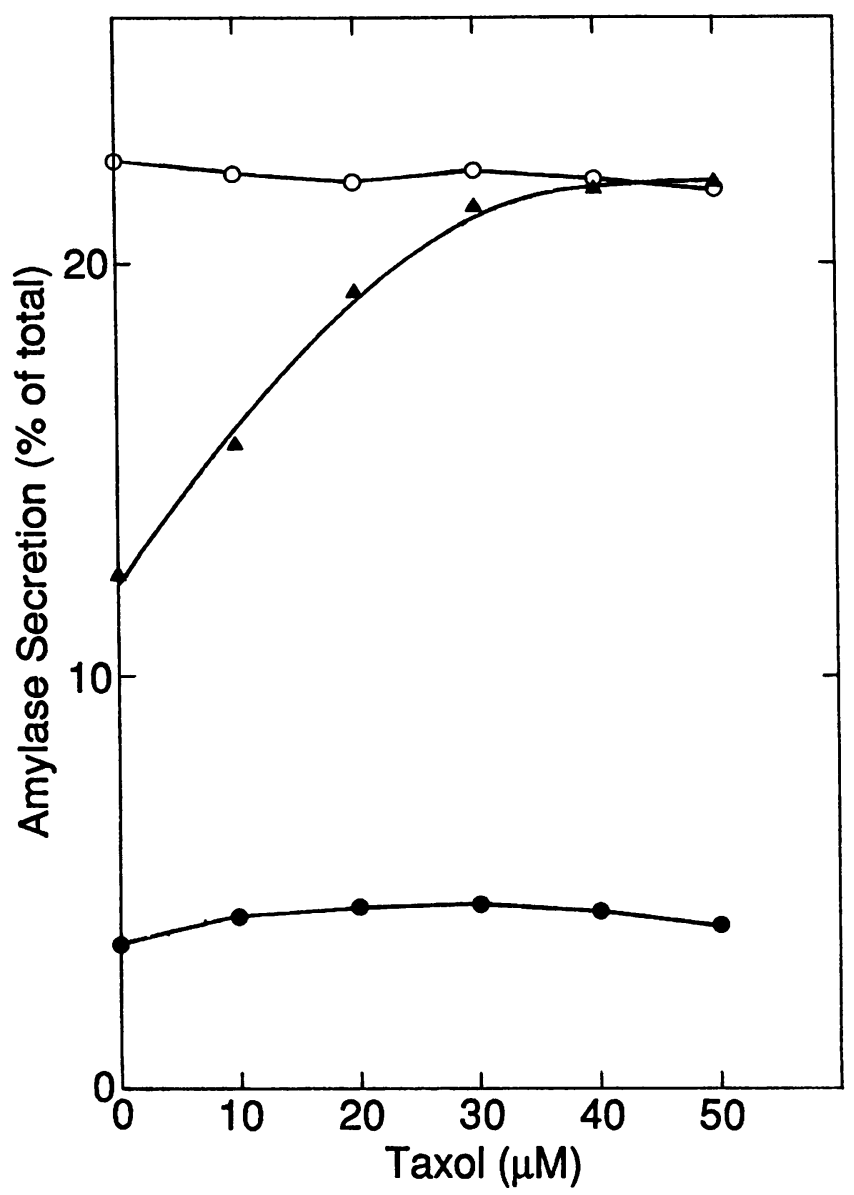

Figure 8. Dose-dependent effect of taxol on in vitro amylase secretion. Rat pancreatic acini were incubated with different concentrations of $\mathrm{CCK}_{\mathbf{8}}$ in the presence of indicated concentrations of taxol. (๑), taxol alone; (o), in combination with $1 \times 10^{-10} \mathrm{M} \mathrm{CCK}_{8} ;(\Delta)$, in combination with $1 \times 10^{-8} \mathrm{M} \mathrm{CCK}_{8}$. The results shown are representative of three independent experiments.

cyclic AMP-dependent protein kinase, calmodulin kinase II, and protein kinase $C$ phosphorylate MAPs and thereby inhibit tubulin polymerization (29-31), and that dephosphorylation of MAPs stimulates microtubule assembly (32). So, phosphorylation of MAPs by some protein kinase activation and/or disorder of dephosphorylation post to the second messenger may cause microtubule disorganization in caerulein-induced pancreatitis.

As the mechanism of the onset of acute pancreatitis, it is suggested that inhibition of pancreatic digestive enzyme secretion in the acinar cell is a significant phenomenon and this phenomenon has recently been the subject of intense consideration (2). This secretory blockade is seen in various experimental models of acute pancreatitis (33) and in most patients of clinical acute pancreatitis (34). For example, in a model of acute hemorrhagic pancreatitis induced by feeding young female mice a choline-deficient, ethionine-supplemented diet (35), pancreatic digestive enzyme secretion is blocked and colocalization of digestive enzyme zymogen with lysosomal hydrolases is observed as well as in caerulein-induced pancreatitis $(36,37)$. In this model, it has been shown that fusion of the zymogen granules with lysosomes (crinophagy) causes the formation of large vacuoles (37). Moreover, recent study has dem- 


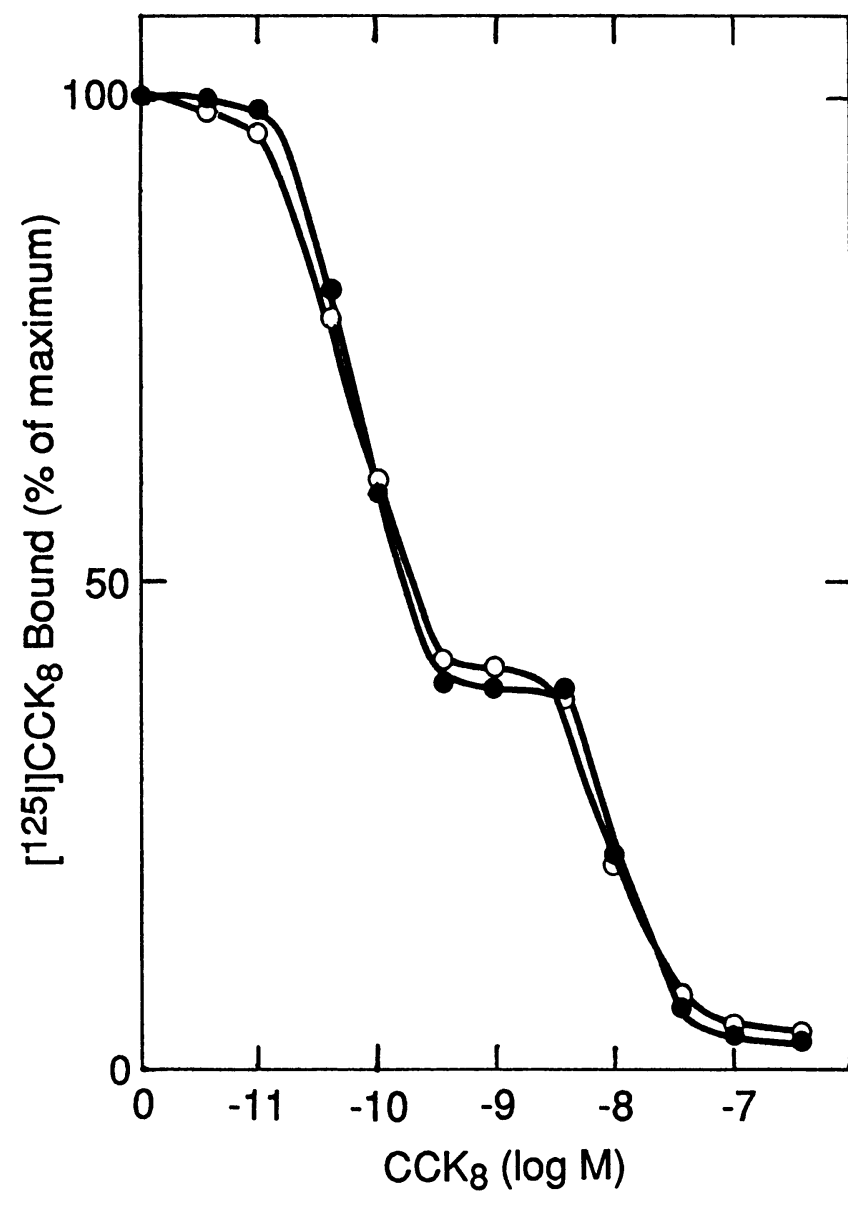

Figure 9. Effect of taxol on competitive inhibition of $\left[{ }^{125} \mathrm{I}\right] \mathrm{CCK}_{8}$ binding to rat pancreatic acini. Rat pancreatic acini were incubated for 120 min at $37^{\circ} \mathrm{C}$ with $5 \mathrm{pM}\left[{ }^{125} \mathrm{I}\right] \mathrm{CCK}_{8}$ and indicated concentrations of unlabeled $\mathrm{CCK}_{8}$ in the presence or absence of $50 \mu \mathrm{M}$ taxol. Binding of $\left[{ }^{125} \mathrm{I}\right] \mathrm{CCK}_{8}$ to acini was expressed as a percentage of $\left[{ }^{125} \mathrm{I}\right] \mathrm{CCK}_{8}$ binding with no unlabeled $\mathrm{CCK}_{8}$ added. (๑), in the presence of taxol; (O), in the absence of taxol. The results shown are representative of three independent experiments.

onstrated that pancreatic duct obstruction also leads this colocalization phenomenon (38). In this model, which seems to be applicable to clinical gall stone pancreatitis, colocalization is found in the zymogen granule-sized organelles. So it is suggested that interfering with a certain process of intracellular transport occurs in these experimental models.

The results of this investigation indicate that microtubule disorganization plays a crucial role in the development of caerulein-induced pancreatitis. However, the involvement of microtubule disorganization in other experimental models and clinical cases is still unknown. It is important to clarify whether microtubule disorganization is involved in other models and clinical cases.

\section{Acknowledgments}

We wish to thank Dr. M. Suffness, Dr. V. Narayanan, and Mrs. N. R. Lomax, National Cancer Institute, for the generous gift of taxol. We also wish to thank Prof. Yoshimi Takai and Dr. Akira Kikuchi (Department of Biochemistry, Kobe University School of Medicine) and Prof. Chizuka Ide and Dr. Akira Mizoguchi (Department of Anatomy, Kobe
University School of Medicine) for their valuable advice, encouragement, and expert technical assistance in this investigation.

This investigation was supported by Grants-in-Aid for Scientific Research from the Ministry of Education, Science, and Culture, Japan (1989).

\section{References}

1. Lampel, M., and H. F. Kern. 1977. Acute interstitial pancreatitis in the rat induced by excessive doses of a pancreatic secretagogue. Virchows Arch. A Pathol. Anat. and Histol. 373:97-117.

2. Steer, M. L., and J. Meldolesi. 1987. The cell biology of experimental pancreatitis. $N$. Engl. J. Med. 316:144-150.

3. Adler, G., G. Rohr, and H. F. Kern. 1982. Alteration of membrane fusion as a cause of acute pancreatitis in the rat. Dig. Dis. Sci. 27:993-1002.

4. Saluja, A., I. Saito, M. Saluja, M. J. Houlihan, R. E. Powers, J. Meldolesi, and M. L. Steer. 1985. In vivo rat pancreatic acinar cell function during supramaximal stimulation with caerulein. Am. J. Physiol. 249:G702-G710.

5. Saito, I., S. Hashimoto, A. Saluja, M. L. Steer, and J. Meldolesi. 1987. Intracellular transport of pancreatic zymogens during caerulein supramaximal stimulation. Am. J. Physiol. 253:G517-G526.

6. Watanabe, O., F. M. Baccino, M. L. Steer, and J. Meldolesi. 1984. Supramaximal caerulein stimulation and ultrastructure of rat pancreatic acinar cell: early morphological changes during development of experimental pancreatitis. Am. J. Physiol. 246:G457-G467.

7. Saluja, A., S. Hashimoto, M. Saluja, R. E. Powers, J. Meldolesi, and M. L. Steer. 1987. Subcellular redistribution of lysosomal enzymes during caerulein-induced pancreatitis. Am. J. Physiol. 251:G508-G516.

8. Stark, H. A., C. M. Sharp, V. E. Sutliff, J. Martinez, R. T. Jensen, and J. D. Gardner. 1989. CCK-JMV-180: a peptide that distinguishes high-affinity cholecystokinin receptors from low-affinity cholecystokinin receptors. Biochim. Biophys. Acta. 1010:145-150.

9. Matozaki, T., J. Martinez, and J. A. Williams. 1989. A new CCK analogue differentiates two functionally distinct $\mathrm{CCK}$ receptors in rat and mouse pancreatic acini. Am. J. Physiol. 257:G594-G600.

10. Saluja, A. K., M. Saluja, H. Printz, A. Zavertnik, A. Sengupta, and M. L. Steer. 1989. Experimental pancreatitis is mediated by low-affinity cholecystokinin receptors that inhibit digestive enzyme secretion. Proc. Natl. Acad. Sci. USA. 86:8968-8971.

11. Kelly, R. B. 1990. Microtubules, membrane traffic, and cell organization. Cell. 61:5-7.

12. Parczyk, K., W. Haase, and C. Kondor-Koch. 1989. Microtubules are involved in the secretion of proteins at the apical cell surface of the polarized epithelial cell, Madin-Darby canine kidney. J. Biol. Chem. 264:16837-16846.

13. Williams, J. A., and M. Lee. 1976. Microtubules and pancreatic amylase release by mouse pancreas in vitro. J. Cell Biol. 71:795-806.

14. Wani, M. C., H. L. Taylor, M. E. Wall, P. Coggon, and A. T. McPhail. 1971. Plant antitumor agents. VI. The isolation and structure of taxol, a novel antileukemic and antitumor agent from Taxus brevifolia. J. Am. Chem. Soc. 93:2325-2327.

15. Rowinsky, E. K., L. A. Cazenave, and R. C. Donehower. 1990. Taxol: a novel investigational antimicrotubule agent. J. Natl. Cancer Inst. 82:1247-1259.

16. Schiff, P. B., J. Fant, and S. B. Horwitz. 1979. Promotion of microtubule assembly in vitro by taxol. Nature (Lond.). 277:665-667.

17. Kumar, N. 1981. Taxol-induced polymerization of purified tubulin. $J$. Biol. Chem. 256:10435-10441.

18. Schiff, P. B., and S. B. Horwitz. 1980. Taxol stabilizes microtubules in mouse fibroblast cells. Proc. Natl. Acad. Sci. USA. 77:1561-1565.

19. De Brabander, M., G. Geuens, R. Nuydens, R. Willebrords, and J. De May. 1981. Taxol induces the assembly of free microtubules in living cells and blocks the organizing capacity of the centrosomes and kinetochores. Proc. Natl. Acad. Sci. USA. 78:5608-5612.

20. Takeyama, Y., H. Nakanishi, H. Ohyanagi, Y. Saitoh, K. Kaibuchi, and Y. Takai. 1986. Enhancement of secretagogue-induced phosphoinositide turnover and amylase secretion by bile acids in isolated rat pancreatic acini. J. Clin. Invest. 78:1604-1611.

21. Miller, L. J., S. A. Rosenzweig, and J. D. Jamieson. 1981. Preparation and characterization of a probe for cholecystokinin octapeptide receptor, $\mathrm{N}^{\alpha}\left({ }^{125} \mathrm{I}\right.$ desaminotyrosyl)CCK 8 , and its interactions with pancreatic acini. J. Biol. Chem. 256:12417-12423.

22. Lowry, O. H., N. J. Rosebrough, A. L. Farr, and R. J. Randall. 1951. Protein measurement with the Folin phenol reagent. J. Biol. Chem. 193:265-275.

23. Irie, A., M. Hunaki, K. Bando, and K. Kawai. 1974. Activation of $\alpha$-amylase in urine. Clin. Chim. Acta. 51:241-245.

24. Nakanishi, H., H. Ohyanagi, Y. Takeyama, H. Onoyama, Y. Saitoh, A. Kikuchi, and Y. Takai. 1988. Mode of inhibitory action of cholecystokinin in amylase release from isolated rat pancreatic acini-inhibition of secretory process 
post to protein kinase C-calcium ion systems. Biochem. Biophys. Res. Commun. 154:1314-1322.

25. Sankaran, H., I. D. Goldfine, A. Bailey, V. Licko, and J. A. Williams. 1982. Relationship of cholecystokinin receptor binding to regulation of biological functions in pancreatic acini. Am. J. Physiol. 242:G250-G257.

26. Wiernik, P. H., E. L. Schwartz, J. J. Strauman, J. P. Dutcher, R. B. Lipton, and E. Paietta. 1987. Phase I clinical and pharmacokinetic study of taxol. Cancer Res. 47:2486-2493.

27. Katsushima, S., H. Adachi, T. Honda, S. Sato, T. Kusui, S. Onishi, E. Aoki, M. Noguchi, and J. Konishi. 1990. Cholecystokinin downregulates receptors for vasoactive intestinal peptide and secretin in rat pancreatic acini. Am. J. Physiol. 258:G395-G403.

28. Howard, W. D., and S. N. Timasheff. 1988. Linkages between the effects of taxol, colchicine, and GTP on tubulin polymerization. J. Biol. Chem 263:1342-1346.

29. Jameson, L., T. Frey, B. Zeeberg, F. Dalldorf, and M. Caplow. 1980. Inhibition of microtubule assembly by phosphorylation of microtubule-associated proteins. Biochemistry. 19:2472-2479.

30. Yamamoto, H., K. Fukunaga, S. Goto, E. Tanaka, and E. Miyamoto 1985. $\mathrm{Ca}^{2+}$, calmodulin-dependent regulation of microtubule formation via phosphorylation of microtubule-associated protein 2, $\tau$ factor, and tubulin, and comparison with the cyclic AMP-dependent phosphorylation. J. Neurochem 44:759-768.

31. Akiyama, T., E. Nishida, J. Ishida, N. Saji, H. Ogawara, M. Hoshi, Y.
Miyata, and H. Sakai. 1986. Purified protein kinase $\mathrm{C}$ phosphorylates microtubule-associated protein 2. J. Biol. Chem. 261:15648-15651.

32. Yamamoto, H., Y. Saitoh, K. Fukunaga, H. Nishimura, and E. Miyamoto. 1988. Dephosphorylation of microtubule proteins by brain protein phosphatases 1 and $2 \mathrm{~A}$, and its effect on microtubule assembly. $J$. Neurochem 50:1614-1623.

33. Niederau, C., M. Niederau, R. Luthen, G. Strohmeyer, L. D. Ferrell, and J. H. Grendell. 1990. Pancreatic exocrine secretion in acute experimental pancreatitis. Gastroenterology. 99:1120-1127.

34. Mitchell, C. J., M. J. Playforth, J. Kelleher, and M. J. McMahon. 1983. Functional recovery of the exocrine pancreas after acute pancreatitis. Scand. $J$. Gastroenterol. 18:5-8.

35. Lombardi, B., L. W. Estes, and D. S. Longnecker. 1975. Acute hemorrhagic pancreatitis (massive necrosis) with fat necrosis induced in mice by DL ethionine fed with a choline-deficient diet. Am. J. Pathol. 79:465-480.

36. Gilliland, L., and M. L. Steer. 1980. Effects of ethionine on digestive enzyme synthesis and discharge by mouse pancreas. Am. J. Physiol. 239:G418G426.

37. Koike, H., M. L. Steer, and J. Meldolesi. 1982. Pancreatic effects of ethionine: blockade of exocytosis and appearance of crinophagy and autophagy precede cellular necrosis. Am. J. Physiol. 242:G297-G307.

38. Saluja, A., M. Saluja, A. Villa, U. Leli, P. Rutledge, J. Meldolesi, and M. Steer. 1989. Pancreatic duct obstruction in rabbits causes digestive zymogen and lysosomal enzyme colocalization. J. Clin. Invest. 84:1260-1266. 